\title{
DINAMIKA RAZVOJA SLOVENSKE ORGELSKE KRAJINE DO NASTOPA CECILIJANSTVA
}

\author{
KATARINA TRČEK MARUŠIČ \\ Znanstvenoraziskovalni center SAZU
}

Izvleček: Na ozemlju današnje Slovenije se je od prvih zametkov oglarstva $v 15$. stoletju pa vse do druge polovice 19. stoletja število orgel iz desetletja $v$ desetletje večalo. Če so bile orgle v začetku 18. stoletja še redke, so v drugi polovici 19. stoletja postale nepogrešljiv tvorec bogoslužja. Z naraščanjem števila na novo izdelanih orgel se je povečevala tudi zavest o pomenu orgelske glasbe pri bogoslužju.

Ključne besede: orglarstvo na Slovenskem, orglarske delavnice, zgodovina orgel

\begin{abstract}
From the beginning of organ-building in the fifteenth century up to the second half of the nineteenth century, the number of organs in Slovenian territory increased from decade to decade. Despite their relative rarity at the beginning of the eighteenth century, they soon became an indispensable part of worship in the second half of the nineteenth century. Along with growing awareness about the importance of organ music, the dynamics of newly-built organs also increased.
\end{abstract}

Keywords: organ-building in Slovenia, organ workshops, organ history

Pričujoča razprava obravnava zgodovinski razvoj postavljanja orgelskih glasbil na Slovenskem od začetkov v prvi polovici 15. stoletja do druge polovice 19. stoletja. Njen namen je: prikazati celostno dinamiko razvoja postavljanja orgelskih glasbil na ozemlju današnje Slovenije skozi pretekla stoletja, in sicer ne glede na lokacijo, ki je bila poleg cerkve namensko lahko tudi kaj drugega; vpeti prikazani razvoj v širši zgodovinski kontekst in ga ovrednotiti s stališča slovenske glasbene in kulturne zgodovine.

Razprava vključuje vse tipe orgelskih glasbil, ki se v splošni jezikovni rabi označujejo kot orgle: portativ, regal, pozitiv in orgle v ožjem pomenu besede. Portativ je najmanjši izmed orgelskih glasbil. Je prenosno enomanualno glasbilo, ki ima največkrat le dvooktavni obseg; glasbilo si organist oprta na rame, tako da lahko z desno roko igra na klaviaturo, z levo pa poganja meh, ki je nameščen na zadnji strani glasbila. Regal je majhno enomanualno glasbilo brez pedala, ki ima le jezičniške registre in je predhodnik harmonija. Glasbilo ima dva klinasta mehova, ki ju poganja kalkant. Pozitiv so manjše štiri- do osemregistrske orgle brez pedala. ${ }^{1}$ Zaradi svoje majhnosti je bil priljubljeno

1 V nekaterih večjih cerkvah so imeli poleg pravih orgel tudi pozitiv, ki se je uporabljal le za igranje pri navadnih delavniških mašah, medtem ko so orgle spremljale praznično bogoslužje. 
glasbilo tudi na gradovih in v zasebnih hišah predvsem plemiških družin. Orgle v ožjem pomenu besede pa so glasbilo, ki ima enega ali več manualov z več registri in tudi pedal. ${ }^{2}$

Obravnavana so le tista orgelska glasbila, ki so bila izdelana za naročnike znotraj današnjih slovenskih meja, torej na ozemlju sodobne države. V teku zgodovine je bilo to ozemlje politično razdeljeno na različne dežele: Kranjsko, Štajersko, Goriško oz. Avstrijsko primorje, Beneško republiko in Madžarsko, cerkveno pa je bilo ozemlje do jožefinskih reform z reko Dravo razmejeno na salzburško nadškofijo in oglejski patriarhat; po jožefinskih reformah pa je razpadlo na škofije: ljubljansko, lavantinsko, goriško, koprsko in tržaško. Ker navedene cerkvene in politične meje ne sovpadajo z mejami, ki ločujejo različna področja orgelske gradnje, in bi bilo že samo zamejevanje na različna področja orgelske gradnje vprašljivo, se raziskava usmerja na sodobno slovensko ozemlje (v političnem smislu), ki ga razume kot kulturnozgodovinsko identiteto.

V razpravo so vključena zgolj tista orgelska glasbila, ki so bila izdelana do časa ustanovitve slovenskega Cecilijinega društva, natančneje do leta 1877. Društvo je prevzelo načrtnejšo skrb za glasbo v cerkvah; prizadevalo si je za njeno ureditev in odpravo tistega, kar naj bi z ozirom na cecilijanske ideale ne sodilo v cerkev. Njihova prizadevanja so vplivala tudi na vlogo orgel pri bogoslužju, ki pa so bile v drugi polovici 19. stoletja pretežno že v vseh župnijskih cerkvah. ${ }^{3}$

Da bi bil prikaz razvoja postavljanja novih glasbil in njegove dinamike do leta 1877 celovit, se razprava osredotoča na sledeča vprašanja: koliko glasbil je do omenjenega časa na Slovenskem obstajalo; kakšna je bila dinamika njihovega postavljanja, torej, kako se je skozi čas spreminjala, večala ali manjšala produkcija orgelskih glasbil; in ali se dinamika postavljanja orgel razlikuje glede na posamezne zgodovinske pokrajine. $Z$ odgovori na ta vprašanja bo podan oris splošnega razvoja slovenske orgelske krajine do konca 19. stoletja.

Da bi bilo mogoče odgovoriti na zastavljena vprašanja, je potrebno zbrati osnovne podatke o vseh orglah, ki so do leta 1877 obstajale na ozemlju današnje Slovenije, ne glede na to, ali še obstojijo ali ne, in ne glede na to, koliko je o njih znanega.

Podatki o orglah so bili zbrani na osnovi zelo obsežne slovenske organološke, organografske in glasbenozgodovinske literature, na osnovi terenskih ogledov, deloma pa tudi na osnovi študija primarnih virov. Na ta način je bilo do leta 1877 mogoče identificirati natančno 779 orgel; od teh jih bodisi v prvotni ali prenovljeni obliki fizično obstoji le še $305 .{ }^{4}$

779 orgel, kolikor jih je bilo mogoče identificirati, gotovo ni vse, kar je do druge polovice 19. stoletja obstajalo na Slovenskem. Nadaljnja raziskovanja bodo nedvomno odkrila še več drugih, nekdaj obstoječih, kasneje pa uničenih glasbil. Vendar je to število dovolj veliko, da dopušča zanesljive splošne sklepe o slovenski orgelski zgodovini in podaja uvid $\mathrm{v}$ rast slovenske orgelske krajine in dinamiko njenega nastajanja.

2 Williams in Thistlethwaite, »Positive«; Williams, »Portative«; Williams, »Regals«; Owen in Williams, »Organ«.

3 O cecilijanskem gibanju razpravlja Aleš Nagode: Nagode, »Starejše slovensko Cecilijanstvo in Gregor Rihar«; Nagode, »Začetki slovenskega Cecilijanstva v luči korespondence med Antonom Foersterjem in Franzon Xaverjem Wittom«.

4 Gl. popis glasbil v razpravi: »Orgle in orgelska glasba v slovenski kulturni zgodovini do nastopa cecilijanstva«, 20-256. Popis vključuje osnovne podatke o vseh 779 orglah, njihove opise in vso literaturo o njih. Nadaljevanje tukajšnje razprave izhaja iz tega popisa. 
Število novih orgel na ozemlju današnje Slovenije se je iz obdobja v obdobje zagotovo večalo. Sprva so bile še izredno redke, v drugi polovici 18. stoletja že razmeroma pogoste, medtem ko so postale stoletje kasneje že nekaj povsem običajnega. Ob tem se zastavlja vprašanje, kakšna je bila rast orgelske produkcije na ozemlju današnje Slovenije po desetletjih, v katerih desetletjih in v katerih delih današnjega slovenskega ozemlja so opazne spremembe in kaj je bil vzrok zanje. Za to so potrebni natančni podatki o času nastanka obravnavanih orgel, ki pa niso vedno znani in tudi niso vedno povsem zanesljivi. Od skupnega števila 779 orgel je točna letnica nastanka znana le za 576 orgel, medtem ko je ostalih 203 možno umestiti le v širši časovni okvir. Število 576 časovno točno določenih orgel je v primerjavi s celotnim številom dovolj visoko, da omogoča zanesljive zaključke glede dinamike postavljanja orgelskih glasbil na Slovenskem. Razprava se v nadaljevanju osredotoča le na teh 576 orgel, za katere je znana letnica njihovega nastanka.

Da bi bilo mogoče nazorno prikazati dinamiko postavljanja orgelskih glasbil, so v tabeli 1 in grafičnem prikazu 1 vsa časovno določena glasbila razvrščena po desetletjih (številke v stolpcih povejo, koliko orgel je bilo postavljeno v posameznih desetletjih). Da bi bilo mogoče opazovati tudi dinamiko naraščanja oz. upadanja števila novih glasbil v posameznih zgodovinskih deželah, na katere je bil današnji slovenski prostor politično razdeljen, so v razpravo vključena glasbila razdeljena v tri pokrajine. Ker so se meje med deželami spreminjale in ker sta današnja slovenska Koroška in Prekmurje geografsko majhni področji, se zdi smiselno celotni slovenski prostor razdeliti na tri področja: Kranjsko, Štajersko s Prekmurjem in Koroško ter slovensko Primorje. V slednje so vključena vsa tista slovenska področja, ki so v 19. stoletju spadala v Avstrijsko primorje.

Kot je razvidno iz tabele 1, je bilo od 576 glasbil do leta 1877 na Kranjskem postavljeno 307 orgel, na Štajerskem (vključno s Koroško in Prekmurjem) 229 in v slovenskem Primorju 40. Število glasbil iz slovenskega Primorja je premajhno, da bi omogočalo realni prikaz dinamike postavljanja orgel, čeprav je njeno naraščanje opazno tudi tu.

Prvi podatek o orglarstvu z ozemlja današnje Slovenije je iz Kopra. Tu je že v drugi polovici 14. stoletja deloval orglar »Magister de Justinopoli«, ki je bil leta 1381 naprošen za izdelavo orgel v cerkvi v Vidmu (Udine). ${ }^{5}$

Koper je do konca 18. stoletja sodil pod Beneško republiko in bil za ozemlje današnje slovenske Primorske strateško pomembno mesto. Zaradi bližine je bil Koper pod neposrednim vplivom gospodarskega in kulturnega središča mesta Trst. V 12. stoletju je bila v Kopru ponovno ustanovljena škofija. ${ }^{6}$ Ker je milanski koncil leta 1287 priznal orgle za edino bogoslužno glasbilo in so orgle v tem obdobju pridobile že pretežno vse pomembnejše stolne cerkve Beneške republike, bi pričakovali, da je tudi koprska škofijska cerkev v tistem času imela orgle. Če so stolne orgle v 14. stoletju zgolj domneva, pa so le-te v 15. stoletju že realnost. Prve orgle so v koprski stolnici zagotovo stale leta 1421, ko se v njej omenja organist. ${ }^{7}$

\footnotetext{
5 Koter, »Izdelovanje glasbil«, 451.

6 Ibid., 452.

7 Radole, L'Arte organaria in Istria, 10; Koter, Glasbilarstvo na Slovenskem, 60; Höfler, »Glasbeniki koprske stolnice v 17. in 18. stoletju«, 140; Trček, »Orgle in orgelska glasba v slovenski kulturni zgodovini do nastopa cecilijanstva«, 21.
} 
Tabela 1: Orgle po desetletjih

\begin{tabular}{|c|c|c|c|c|}
\hline Desetletje & Primorje & Kranjska & Štajerska & Celotno ozemlje \\
\hline $1420-1429$ & 1 & & & 1 \\
\hline $1430-1439$ & & & & \\
\hline $1440-1449$ & & & & \\
\hline $1450-1459$ & & & & \\
\hline $1460-1469$ & & & & \\
\hline $1470-1479$ & & & & \\
\hline $1480-1489$ & & 1 & & 1 \\
\hline $1490-1499$ & & 1 & & 1 \\
\hline $1500-1509$ & & & 1 & 1 \\
\hline $1510-1519$ & 1 & & & 1 \\
\hline $1520-1529$ & & & & \\
\hline $1530-1539$ & 3 & 1 & & 4 \\
\hline $1540-1549$ & & 1 & & 1 \\
\hline $1550-1559$ & & 1 & & 1 \\
\hline $1560-1569$ & & 1 & & 1 \\
\hline $1570-1579$ & 1 & & 1 & 2 \\
\hline $1580-1589$ & & & 1 & 1 \\
\hline $1590-1599$ & 1 & 2 & 1 & 4 \\
\hline $1600-1609$ & & 2 & 1 & 3 \\
\hline $1610-1619$ & & 3 & & 3 \\
\hline $1620-1629$ & & 5 & 1 & 6 \\
\hline $1630-1639$ & 2 & 4 & & 6 \\
\hline $1640-1649$ & & 3 & & 3 \\
\hline $1650-1659$ & & & 1 & 1 \\
\hline $1660-1669$ & 2 & 2 & 3 & 7 \\
\hline $1670-1679$ & & 1 & 1 & 2 \\
\hline $1680-1689$ & & 4 & 4 & 8 \\
\hline $1690-1699$ & & 5 & 3 & 8 \\
\hline $1700-1709$ & & 3 & 2 & 5 \\
\hline $1710-1719$ & & & 2 & 2 \\
\hline $1720-1729$ & 1 & 1 & 7 & 9 \\
\hline $1730-1739$ & & 7 & 10 & 17 \\
\hline $1740-1749$ & 1 & 10 & 7 & 18 \\
\hline $1750-1759$ & 2 & 7 & 9 & 18 \\
\hline $1760-1769$ & & 14 & 12 & 26 \\
\hline $1770-1779$ & 3 & 3 & 10 & 16 \\
\hline $1780-1789$ & 1 & 10 & 6 & 17 \\
\hline 1790-1799 & 2 & 3 & 7 & 12 \\
\hline 1800-1809 & 3 & 7 & 7 & 17 \\
\hline $1810-1819$ & & 1 & 5 & 6 \\
\hline $1820-1829$ & 1 & 19 & 10 & 30 \\
\hline $1830-1839$ & & 29 & 15 & 44 \\
\hline $1840-1849$ & 1 & 29 & 31 & 61 \\
\hline
\end{tabular}




\begin{tabular}{|c|c|c|c|c|}
\hline Desetletje & Primorje & Kranjska & Štajerska & Celotno ozemlje \\
\hline $1850-1859$ & 4 & 50 & 23 & 77 \\
\hline $1860-1869$ & 6 & 43 & 25 & 74 \\
\hline $1870-1877$ & 4 & 34 & 23 & 61 \\
\hline
\end{tabular}

Prvim zametkom oglarstva na ozemlju današnje Slovenije sledi polstoletni premor, ko o morebitnih novih orglah nimamo nobenih podatkov (gl. grafični prikaz 1). Verjetno je razlog za nepoznavanje obstoja zgodnjih orgel zgolj pomanjkanje arhivskega gradiva, morda pa je razlog tudi v takratnem splošnem dogajanju. V 15. stoletju so namreč ozemlje današnje Slovenije prvič zajeli turški vpadi. Ti so leta 1415 dosegli Ljubljano. Kljub temu, da je temu sledilo polstoletno zatišje, so prebivalci to obdobje izkoristili za popravilo škode, utrjevanje mest in druge intenzivne priprave na morebitne nove napade. ${ }^{8}$

V letih 1485-1487 je oglejski del današnjega slovenskega ozemlja pregledovala oglejska vizitacijska komisija. Ohranil se je dnevnik njenega tajnika, Paola Santonina, v katerem so med drugim tudi opisi vokalne in instrumentalne glasbe, kakršno je vizitacijska komisija slišala v posameznih cerkvah. Santonino poroča, da so v več samostanskih in župnijskih cerkvah (Slovenske Konjice/sv. Jurij, Velesovo/dominikanke, Škofja Loka/ klarise) prisostvovali odličnim glasbenikom. Čeprav ne omenja zmeraj konkretnih glasbil, lahko domnevamo, da so bile prisotne tudi orgle. ${ }^{9}$ Omenjeno domnevo potrjuje dejstvo, da so samostanske cerkve današnje avstrijske Štajerske dobile orgle v 14., zagotovo pa v 15. stoletju. Ti vplivi so segli tudi na ozemlje današnje Slovenije, ${ }^{10}$ saj seže vedenje o obstoju prvih glasbil že v konec 15. stoletja; Santonino v letu 1486 namreč omenja prve orgle na Kranjskem: v župnijski cerkvi v Kranju je bilo mogoče prisluhniti kvalitetni vokalni glasbi in novim orglam, ki jih je naročil in plačal takratni župnik Matija Operta. ${ }^{11}$ Kranjska župnija bi zgled za ureditev cerkvene glasbe lahko našla v cerkvi sv. Jakoba v Beljaku. Slednja je bila zaradi svoje lege pod močnim italijanskim in nemškim vplivom, imela je bogato glasbeno produkcijo, vse pomembne tvorce bogoslužne glasbe in v tem času tudi že orgle. ${ }^{12}$

S konca 15. stoletja je znano tudi poročilo iz Starega trga pri Ložu. Župnija Stari trg pri Ložu se omenja že leta 1160. Pod njeno upravo so spadale okoliške župnije: Bloke, Loški Potok, Sveti Vid nad Cerknico, Sveta Trojica, Babno polje in Prezid. ${ }^{13}$ Starološka župnijska cerkev sv. Jurija je bila zato najpomembnejša cerkev na tem ozemlju. Ni nenavadno, da se že leta 1494 v njej omenja prvi organist, iz česar lahko sklepamo, da so tega leta imeli tudi orgle.

Ker iz Santoninovega pisanja o glasbi na ozemlju današnje Slovenije ni zaznati nikakršnih presenečenj ali začudenj nad slišanim, lahko sklepamo, da mu je bila na

8 Slekovec, »Turki na Slovenskem Štajerskem. Spominki iz domače zgodovine«, 9; Voje, Slovenci pod pritiskom turškega nasilja, 141.

9 Santonino, Popotni dnevniki; Snoj, »Pisna pričevanja o glasbi v ustnem izročilu«, 305-308.

${ }^{10}$ Heinz, Frühbarocke Orgeln in der Steiermark, 25.

${ }^{11}$ Santonino, Popotni dnevniki, 41, 183; Snoj, »Pisna pričevanja o glasbi v ustnem izročilu«, 306.

${ }^{12}$ Cvetko, Zgodovina glasbene umetnosti na Slovenskem, 1:42; Santonino, Popotni dnevniki, 48; Snoj, »Pisna pričevanja o glasbi v ustnem izročilu«, 307.

${ }^{13}$ Kebe, Loška dolina z Babnim Poljem, 33, 368-369. 
Grafični prikaz 1: Rast števila orgel po desetletjih

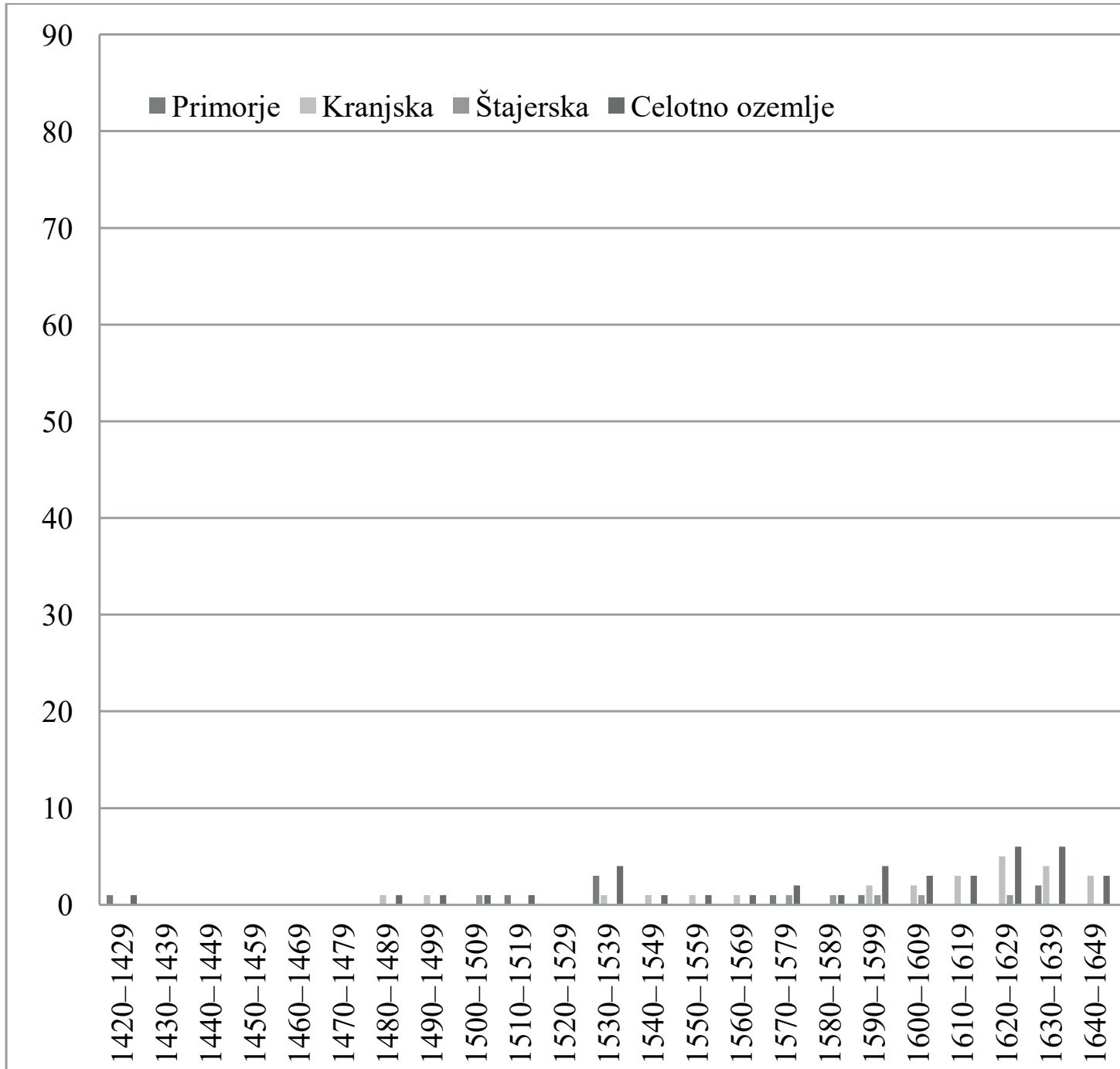


vizitacijah slišana glasba »domača« in enakovredna tisti, ki jo je poznal iz svojega okolja. Omenjena opazka vodi do sklepa, da je bila glasba slovenskih dežel primerljiva s takratno zahodnoevropsko glasbo. ${ }^{14}$ Ker so bile orgle v zahodnoevropskih cerkvah v tem času že uveljavljene in prisotne $\mathrm{v}$ bogoslužni glasbi, smemo pričakovati, da je bilo podobno tudi na današnjem Slovenskem.

Bližnja avstrijska in italijanska mestna središča so imela v 16. stoletja močan kulturni razvoj in pričakovali bi, da je vpliv že zaradi neposredne bližine in stikov prodrl tudi v slovenske dežele. Vendar temu ni bilo tako. Razlog za zastoj napredka bi lahko bile slabe družbene razmere; želja po ekonomski blaginji fevdalcev, vladarjev in cerkve je poglabljala razlike med družbenimi sloji, zaradi česar so se pričeli kmečki upori, poleg tega pa še močni turški vpadi. To je imelo negativne posledice na kulturni razvoj slovenskih dežel v 16. stoletju, tudi na razvoj orglarstva. Vse do zadnjega desetletja 16. stoletja je namreč iz vsakega desetletja znano največkrat le po eno glasbilo. Orgle so v tem času pridobile predvsem stolne in mestne cerkve. V četrtem desetletju izstopajo obalna mesta (Piran, Koper, Izola), ki so v 16. stoletju še pripadala Beneški republiki in bila zato podvržena bistveno drugačnim vplivom kot osrednje slovenske pokrajine. V deželi Kranjski in vojvodini Štajerski sta orgle pridobili le mariborska mestna cerkev in ljubljanska stolnica. Izjema je župnijska cerkev v Škofji Loki, ki je bila do leta 1532 še del župnije Stara Loka. Po pridobitvi vikariata in po zaključku njene celovite prenove leta 1532 se leto kasneje v njej že omenja organist..$^{15}$

V 16. stoletju se je na ozemlju današnje Slovenije pričel širiti protestantizem. Z njegovim razmahom je cerkvena glasba postala sredstvo za podajanje protestantskega nauka. Protestantje s Primožem Trubarjem na čelu so jo pospešeno spodbujali in gojili. Trubar že v posvetilu pesmarice Eni psalmi poudarja pomen glasbe in v njem omenja celo regal, ki je bil leta $1567 \mathrm{v}$ uporabi pri protestantskem bogoslužju v ljubljanski cerkvi sv. Elizabete. Da je imela glasba v protestantskem bogoslužju pomembno vlogo, potrjuje tudi dejstvo, da so že čez dobrih dvajset let pridobili že drugo, večje orgelsko glasbilo, pozitiv. ${ }^{16}$

Konec 16. stoletja je prišlo do temeljitih verskih in družbenih sprememb, ki so bile znanilke novih časov. Spremenjene razmere so se odražale tudi v dinamiki nastajanja slovenske orgelske krajine. Iz časa od 1590 pa vse do 1709 imamo iz vsakega desetletja po nekaj novih orgel (tri, štiri, največ osem, gl. tabelo 1). Natančno število glasbil v posameznih desetletjih se sicer dozdeva naključno, vsekakor pa je očitno, da se je v primerjavi s 16. stoletjem povečalo. Poleg pomembnih stolnih in župnijskih cerkva so glasbila dobile tudi že samostanske in oddaljene župnijske cerkve. Med vidnejšimi je leta 1473 dokončno opuščeni benediktinski samostan v Gornjem Gradu, ki ga je kot rezidenco prevzela ljubljanska škofija. S tem se je glasba v Gornjem Gradu vidno razmahnila. Veliko zaslug za to je imel takratni škof Tomaž Hren, katerega naloga je bila prenova cerkve po načelih

${ }^{14}$ Höfler, Tokovi glasbene kulture na Slovenskem, 22; Cvetko, Zgodovina glasbene umetnosti na Slovenskem, 1:45.

${ }^{15}$ Rijavec, Glasbeno delo na Slovenskem v obdobju protestantizma, 28. Rijavec se glede škofjeloškega organista sklicuje na regeste, ki mu jih je iz münchenskega okrožnega in münchenskega glavnega mestnega arhiva posredoval Pavle Blaznik. Škulj, »Orgle v dekaniji Škofja Loka«, 285.

${ }^{16}$ Trubar, Eni psalmi; Rijavec, Glasbeno delo na Slovenskem v obdobju protestantizma, 102. 
Tridentinskega koncila (1545-1563). Tomaž Hren je v Gornjem Gradu ustanovil semenišče Collegium Marianum in si prizadeval za dobro glasbeno izobrazbo duhovnikov. V sklop teh prizadevanj sodi nakup kar dveh cerkvenih orgel med leti 1599 in 1606 (zgolj v času sedmih let), poleg tega pa še obogatitev rezidenčnega inventarja s tremi manjšimi novimi orgelskimi glasbili. ${ }^{17}$ Morda je s temi nakupi povezan tudi obstoj orgel v bližnji vikariatni in romarski cerkvi v Novi Štifti (Tirosek); le-te je leta 1617 skupaj z ostalimi gornjegrajskimi glasbili po naročilu Tomaža Hrena popravljal Isaac Posch. ${ }^{18}$

Produkcija novih orgel je bila v prvi polovici 17. stoletja največja na Kranjskem. K temu so najopazneje pripomogli redovi; najvidnejši med njimi so bili ljubljanski jezuiti. Ti so se v Ljubljani nastanili leta 1595. Čeprav so jezuiti v 16. stoletju sprva zavračali vsakršno pretirano glasbeno dejavnost, se je njihovo dojemanje glasbe spremenilo in $\mathrm{v}$ 17. stoletju močno razbohotilo. ${ }^{19}$ Rezultat tega so bila tudi kar štiri orgelska glasbila, ki so jih jezuiti pridobili zgolj v prvih šestindvajsetih letih 17. stoletja. ${ }^{20}$

Čeprav so bila orgelska glasbila prvenstveno namenjena liturgiji, imamo iz 17. stol. tudi podatke o drugačni, posvetni rabi orgel. Leta 1622 so v cistercijanski opatiji v Kostanjevici na Krki z orglami spremljali obed. Iz 17. stoletja so poznana orgelska glasbila v zasebni lasti; srečamo jih na gradovih ali v zasebnih plemiških hišah. Na gradu Ig, ki ga je leta 1581 kupil Janez pl. Englshauser, so bile leta 1618 tudi orgle. ${ }^{21}$ Iz zapuščinskega inventarja Janeza Jurija Lamberga za leto 1629 je razvidno, da je v hiši na Novem trgu v Ljubljani (takrat št. 8), ki je bila med leti 1619 in 1629 v njegovi lasti, imel pozitiv. ${ }^{22}$ Poročila o orgelskih glasbilih so se ohranila tudi z ozemlja današnje slovenske Štajerske. Leta 1614 se v zapuščinskem inventarju Franca Gall-Gallensteina z gradu Rajhenburg omenjajo majhne orgle, najbrž pozitiv, ki je bil v orožarni. ${ }^{23}$ Leta 1668 pa je bil po naročilu Georga Friedricha, grofa Sauer izdelan pozitiv za grad Borl v Dolanah. Pozitiv je

17 Škulj, Beneške orglarske delavnice, 13-14; Höfler, »Glasbena kapela ljubljanske stolnice v drugi polovici 17. stoletja«, 143; Kokole, Isaac Posch, 46-53, zlasti 48, 49.

18 Škulj, Baročne orglarske delavnice, 7; Kokole, Isaac Posch, 278.

${ }^{19}$ Cvetko, Zgodovina glasbene umetnosti na Slovenskem, 1:185-186.

${ }^{20} \mathrm{~V}$ samostanskih cerkvah na ozemlju današnje Slovenije se organisti in orgle pojavljajo predvsem od druge polovice 17. stoletja dalje. Iz zadnjih let 17. stoletja so znana 3 orgelska glasbila iz cistercijanskih samostanov v Stični in Kostanjevici na Krki, od leta 1650 dalje pa se omenjajo tudi organistke iz dominikanskega samostana v Radljah ob Dravi (Ana Marta Prensteiner, Marija Barbara Raditschnig, Jožefa, baronica Rosenberg). Pucelj, Idiographia sive Rerum memorabilium Monasterii Sitticensis Descriptio (1719); Škulj, Baročne orglarske delavnice, 15-16, 37; Mlinarič, Stiška opatija 1136-1784, 565, 578, 652, 716, 717, 770; Mlinarič, Kostanjeviška opatija 1234-1786, 67, 380, 487; Mlinarič, Marenberški dominikanski samostan 1251-1782, 278, 277, 280; »Kronika samostana Marenberg 1686-1712«, 222-224, 629-631, 657-664; gl. tudi: Škulj, Orgle v Ljubljani, 56, 121-122, 140; Zadnikar, Samostan Stična in njegove znamenitosti, 121, 151; Bizjak in Škulj, Orgle na Slovenskem, 12.

${ }^{21}$ Koter, Glasbilarstvo na Slovenskem, 50, 73; Trček, »Orgle in orgelska glasba v slovenski kulturni zgodovini do nastopa cecilijanstva«, 29.

${ }^{22}$ Koter, Glasbilarstvo na Slovenskem, 73; Fabjanič, Knjiga ljubljanskih hiš in njenih stanovalcev, 130.

${ }^{23}$ Slana, »Lastniki Rajhenburga med 16. in 19. stoletjem (1570-1881)«, 528-529. 
bil prvotno postavljen v grajski dvorani, kar dokazuje njegovo uporabo pri poustvarjanju posvetne glasbe. ${ }^{24}$

Zdi se, da v 17. stoletju orgle niso bile več nekaj povsem izjemnega; čeprav so bile še zmeraj redke, so bile prisotne v cerkvenem, v manjši meri pa tudi v posvetnem okolju. Srečamo jih v cerkvah vseh statusov (stolna, župnijska, samostanska, podružnična, romarska, itd.) Orgelska glasbila so bila v prvi vrsti del pomembnih stolnih, mestnih in samostanskih cerkva, vstopala pa so tudi v glasbeno življenje plemiških družin. Cerkve nižjega statusa so bile pri pridobitvi orgelskega glasbila pogosto odvisne od finančne podpore tamkajšnje grajske gospode ali cerkvenih dostojanstvenikov. Pomembnejše lokalne romarske oz. podružnične cerkve so podpirali predvsem graščaki.

Čeprav so orgelsko produkcijo na ozemlju današnje Slovenije do začetka 18. stoletja pokrivali predvsem gostujoči orglarji (glej tabelo 2), ${ }^{25}$ bi spremenjene razmere lahko povezali z dejstvom, da sta v 17. stoletju na ozemlju današnje Slovenije odprla orglarski delavnici vsaj dva orglarja: Thomas Khrueg in Johann Faller (gl. grafični prikaz 2). Kljub temu, da njuna danes poznana opusa nista obsežna, bi k večji produkciji lahko pripomogla že zaradi nudenja orglarskih storitev na »domačem《 ozemlju naročnikov.

Tabela 2: Seznam na Slovenskem delujočih orglarjev do začetka 18. stoletja

\begin{tabular}{|l|c|c|}
\hline Orglar & Obdobje delovanja & Št. orgel \\
\hline Giacomo Vicentino & 1516 & 1 \\
\hline Piero de Zuanne & 1534 & 1 \\
\hline Vicentino (bratje) & 1535 & 1 \\
\hline Jacomo di Venezia & 1538 & 1 \\
\hline Michael Teispacher & 1551 & 1 \\
\hline Ulrich & 1586 & 1 \\
\hline Vincenzo Colonna & 1596,1606 & 3 \\
\hline Isaac Posch & 1621 & 1 \\
\hline Weg & 1627 & 1 \\
\hline Paul Rotenburger & 1641 & 1 \\
\hline Thomas Khrueg & ok. $1640-1650$ & 1 \\
\hline Rudolf Rapolt & 1668 & 1 \\
\hline Johann Faller & $1680-$ zač. 18 . stol. & 3 \\
\hline Jacob Hägglinger & 1696 & 1 \\
\hline
\end{tabular}

Grafični prikaz 1 kaže, kako se je do tridesetih let 18. stoletja na današnjem slovenskem ozemlju počasi prebujalo orglarstvo; vse do dvajsetih let 18. stoletja je bil center oglarstva na današnjem slovenskem ozemlju v Ljubljani. Tu sta po Johannu Fallerju delovala še Andreas Sebastian Wallenstein in Johann Michael Steinhoffer (gl. grafični prikaz 2). V dvajsetih letih 18. stoletja pa se prvi orglarji pojavijo tudi na ozemlju današnje slovenske Štajerske; v Celje je takrat prišel Joannes Franciscus Janechek (Janez Frančišek Janeček), ki je ok. leta 1722 tu ustanovil prvo orglarsko delavnico. Njeno tradicijo sta po Janechkovi

${ }^{24}$ Klemm in Kušćer, Pozitiv Rudolfa Rapoldta u gradskom muzeju Varaždin 1668-2007, 7; Ciglenečki, »Oprema gradov na slovenskem Štajerskem od srede 17. do srede 20. stoletja«, 18.

${ }^{25}$ Orglarski mojstri, ki so imeli delavnico na ozemlju današnje Slovenije, so v tabeli 2 potemnjeni. 
smrti nadaljevala njegov učenec Anton Scholz in za njim Wenzel Marthal. V dobrem stoletju delovanja je za naročnike na ozemlju današnje Slovenije nastalo v njej 56 orgel. Kot protiutež Janechkovi delavnici bi lahko videli delavnico Marcusa Göbla, ki je bila slabih dvajset let kasneje (ok. 1739) ustanovljena v Ljubljani. Njegova naslednika sta bila Göblov učenec Johann Georg Eisl in za njim Joseph Alois Kutschera. V slabih sedemdesetih letih je bilo v njej izdelanih 37 orgel za naročnike na današnjem slovenskem ozemlju. ${ }^{26}$

Tabela 3: Seznam na Slovenskem delujočih orglarjev v 18. stoletju

\begin{tabular}{|c|c|c|}
\hline Orglar & Obdobje delovanja & Št. orgel \\
\hline Johann Andreas Schwarz & 1700-1. pol. 18. stol. & 6 \\
\hline Andreas Sebastian Wallenstein & 1709 & 1 \\
\hline Osvaldo Carlone & 1707 & 1 \\
\hline Štefan Habersack & 1720 & 1 \\
\hline Johann Michael Steinhoffer & $1720-1744$ & 4 \\
\hline Janez Mihael Heiller & 1722 & 1 \\
\hline Joannes Franciscus Janechek & $1725-1776$ & 40 \\
\hline Johann Georg Mitterreiter & $1726-1737$ & 4 \\
\hline Ferdinand Schwarz & $1737-1760$ & 2 \\
\hline Marcus Göbl & $1741-1751$ & 4 \\
\hline Pietro Nacchini & 1746 & 1 \\
\hline Köblitz & 1. pol. 18. stol. & 1 \\
\hline Anton Josef Römer & $1751-1764$ & 2 \\
\hline Johann Georg Eisl & $1753-1780$ & 17 \\
\hline Franciscus Xaverius Crisman & $1760-$ pr. 1773 & 5 \\
\hline Simon Ottonitscher & $1762-1771$ & 5 \\
\hline Francesco Dacci & $1770-1780$ & 1 \\
\hline Gaetano Antonio Callido & $1771-1796$ & 6 \\
\hline Franz Xaver Schwarz & $1775-1794$ & 2 \\
\hline Francesco Comelli & $1775-1800$ & 1 \\
\hline Kunath & 1780 & 1 \\
\hline Joseph Alois Kutschera & $1780-1809$ & 8 \\
\hline Anton Scholz & $1781-1804$ & 8 \\
\hline Agostino, Antonio Callido & 1794 & 1 \\
\hline Joseph Ottonitsch & $1795-1832$ & 7 \\
\hline Matija Hennig & 18. stol. & 1 \\
\hline
\end{tabular}

Plodovite delavnice, ki so v 18. stoletju delovale na Kranjskem in v slovenskem delu Štajerske, so tujim gostujočim orglarjem odvzele velik del naročil. Prisotnost domačih mojstrov, predvsem pa njihova kvaliteta, sta pozitivno vplivali na število novih naročil. Gostujoči orglarji so bili v 18. stoletju dejavni predvsem v tistih predelih današnjega slovenskega ozemlja, kjer ni bilo lokalnih orglarjev in orglarskih delavnic; na ozemlju današnje Primorske so poleg Franciscusa Xaveriusa Crismana (Franc Ksaverij Križman), ki je tu deloval le dobro desetletje, bili še vedno dejavni zlasti italijanski orglarji, na

26 Trček Marušič, »The Tradition of Göbl’s Organ Workshop«, 193-200. 
ozemlju zgornjega dela Štajerske (vključno s Koroško in Prekmurjem) pa graški orglarji. ${ }^{27}$ Slednji so bili v manjšem obsegu prisotni tu tudi potem, ko je v drugi polovici 18. stoletja v Mariboru odprl svojo orglarsko delavnico Simon Ottonitscher (gl. tabelo 3). ${ }^{28}$

Razlog za porast števila novih orgel v četrtem desetletju 18. stoletja je morda tudi v samem razvoju glasbene umetnosti. V 18. stoletju je namreč v ospredje prišla instrumentalna glasba, kar je neposredno vplivalo na rast zavesti o pomenu orgel in orgelske glasbe pri bogoslužju. V letih od 1730 do 1739 je nastalo vsaj sedemnajst orgel (gl. tabelo 1) in tako je bilo tudi v nadaljnjih desetletjih, vse do konca prvega desetletja 19. stoletja. Iz vsakega desetletja tega obdobja imamo podatke o približno enako visokem številu novih glasbil. Največ jih je bilo v desetletju od 1760 do 1769 (26) in najmanj v zadnjem desetletju 18. stoletja (12). Čeprav je obdobje od 1730 do 1809 dolgo, ni mogoče reči, da bi orgelska produkcija v tem času konstantno naraščala, kljub temu pa je bila očitno mnogo večja kot v poprejšnjem obdobju. Nenadno porast števila glasbil po letu 1730 je mogoče razlagati tudi z ekonomskega vidika. Očitno je proti sredini stoletja število cerkva, ki so imele dovolj sredstev, da so naročile orgle, naraslo. Še vedno pa je bilo v veliki meri prisotno tudi mecenstvo, ki je finančno šibkejšim cerkvam omogočilo nakup orgel. Orgle so bile torej še vedno v veliki meri simbol blagostanja.

Medtem ko je bila produkcija orgelskih glasbil od sredine 18. stoletja dalje razmeroma konstantna, je v drugem desetletju 19. stoletja nenadno močno upadla, saj so iz desetletja od 1810 do 1819 znani podatki le za šest novih orgel (gl. tabelo 1). V tem desetletju je tudi opazen upad števila orglarskih delavnic; na Kranjskem se je s smrtjo Josefa Aloisa Kutschere leta 1809 zaključilo delovanje delavnice Marcusa Göbla, Franciscus Xaverius Crisman pa je konec 18. stoletja deloval zgolj na ozemlju današnje Avstrije. Po slabem desetletju se je na Kranjskem orglarstvo ponovno prebudilo leta 1818, ko je v Cerknico prišel orglar Johann Gottfried Kunath (gl. grafična prikaza 2 in 4).

Na ozemlju slovenske Štajerske sta v tem času delovali dve delavnici: v Celju pod vodstvom Wenzla Marthala Janechkova delavnica, v Mariboru pa pod vodstvom Josepha Ottonitscha delavnica Simona Ottonitscherja. Temu primerno je tudi število izdelanih glasbil: z ozemlja slovenske Štajerske je znano pet orgel, medtem ko je bilo na Kranjskem po zbranih podatkih $v$ omenjenem desetletju izdelano le eno glasbilo. Eden od glavnih vzrokov za nenaden vpad produkcije novih orgel na Kranjskem je bil gotovo pomanjkanje orglarjev. Poleg tega je vpad mogoče povezovati s političnimi razmerami, se pravi z Napoleonovimi vojnami; Kranjska je bila namreč priključena Ilirskim provincam, medtem ko je ozemlje današnje slovenske Štajerske ostalo v Habsburški monarhiji. Vse to se je očitno močno odražalo tudi v orglarstvu.

Na prehodu iz 18. v 19. stoletje so bile razmere na slovenskih korih nenadzorovane in neurejene. Bogoslužno glasbo so vodili bolj in manj izobraženi organisti, ki so pogosto tudi improvizirali, pri čemer so v svoje improvizacije vpletali posvetne melodije. Ker orgel še

${ }^{27}$ Obrobno velja omeniti, da je v Slovenski Bistrici v dvajsetih letih 18. stoletja deloval mizar Janez Mihael Heiler, ki je bil znan tudi kot orglarski mojster. Orglarstvo je domnevno opravljal le v majhnem obsegu. Weigl, »Prenova gradu Podčetrtek v letih 1715-1723«, 37.

${ }^{28} \mathrm{~V}$ tabeli 3 so orglarski mojstri, ki so imeli delavnico na ozemlju današnje Slovenije, potemnjeni. 
ni bilo v vseh cerkvah, so pri bogoslužju pogosto sodelovali razni drugi instrumentalisti in instrumentalne skupine, ki so igrali predvsem posvetne skladbe. ${ }^{29}$

Številni glasbeniki, cerkveni in posvetni, so opozarjali na slabe razmere in se lotili prenove bogoslužne glasbe, pri čemer so orglam pripisali velik pomen: postale so nepogrešljivo in za bogoslužje edino primerne glasbilo, bodisi v spremljevalni ali pa v solistični vlogi. ${ }^{30}$

Ureditev bogoslužne glasbe in želja, da bi glasbena umetnost dosegla čim širši krog ljudi vseh družbenih slojev, je posredno vplivala tudi na razmere v orglarstvu. Očitna težnja, da bi imele vse župnijske cerkve orgle, se je pokazala že v dvajsetih letih 19. stoletja, ko je prišlo do ponovnega zagona orglarske umetnosti. Iz tega desetletja imamo namreč podatke o kar 30 novih glasbilih. A kljub visokemu številu na novo izdelanih glasbil in na prvi pogled konstantni produkciji se pri podrobni analizi pokaže, da se je orglarstvo na ozemlju slovenske Štajerske še vedno soočalo z zastojem; centra orglarske umetnosti sta še nadalje ostala Celje in Maribor. V Celju sledimo neprekinjenemu orglarstvu vse do leta 1825, ko je umrl zadnji orglar Janechkove delavnice Wenzel Marthal. Tega leta se je produkcija orgel v Celju za 17 let prekinila (gl. grafični prikaz 3). Šele leta 1842 je tu delavnico odprl Alois Hörbiger, ki je v času svojega delovanja v Celju vzgojil tudi dobršen del kasnejših štajerskih orglarjev (Naraks, Zeichen, Ebner).

Tabela 4: Seznam na Slovenskem delujočih orglarjev do leta 1840

\begin{tabular}{|l|c|c|}
\hline Orglar & Obdobje delovanja & Št. orgel \\
\hline Joseph Alois Kutschera & $1780-1809$ & 8 \\
\hline Anton Scholz & $1781-1804$ & 8 \\
\hline Agostino, Antonio Callido & 1794 & 1 \\
\hline Joseph Ottonitsch & $1795-1832$ & 7 \\
\hline Matija Hennig & 18. stol. & 1 \\
\hline Francesco Merlini & 1805 & 1 \\
\hline Pietro Antonio Bossi & $1801-1825$ & 4 \\
\hline Wenzel Marthal & $1803-1825$ & 8 \\
\hline Ludwig Greßmann & 1810 & 1 \\
\hline Mihael Rupnik & $1869-1871$ & 14 \\
\hline Johann Gottfried Kunath & $1820-1840$ & 53 \\
\hline Peter Rumpel & $1821-1861$ & 1 \\
\hline Karl Spel & 1824 & 1 \\
\hline Mathias Krainz & $1824-1850$ & 6 \\
\hline A. J. & 1827 & 1 \\
\hline Karl Schehl & $1830-1850$ & 1 \\
\hline Anton Oton & 1830 & 1 \\
\hline Franz Schehl & 1833 & 1835 \\
\hline Jakob Matzinger & & \\
\hline
\end{tabular}

${ }^{29}$ Cvetko, Zgodovina glasbene umetnosti na Slovenskem, 2:241, 244; Mašek, »O cerkvenem petji in orglanji po deželi«, 170.

${ }^{30}$ Mašek, »O cerkvenem petji in orglanji po deželi«, 170-171, 182-183, 190-191, 198, 207, 214, 274. 
Grafični prikaz 2: Slovenski orglarji 18. stoletja

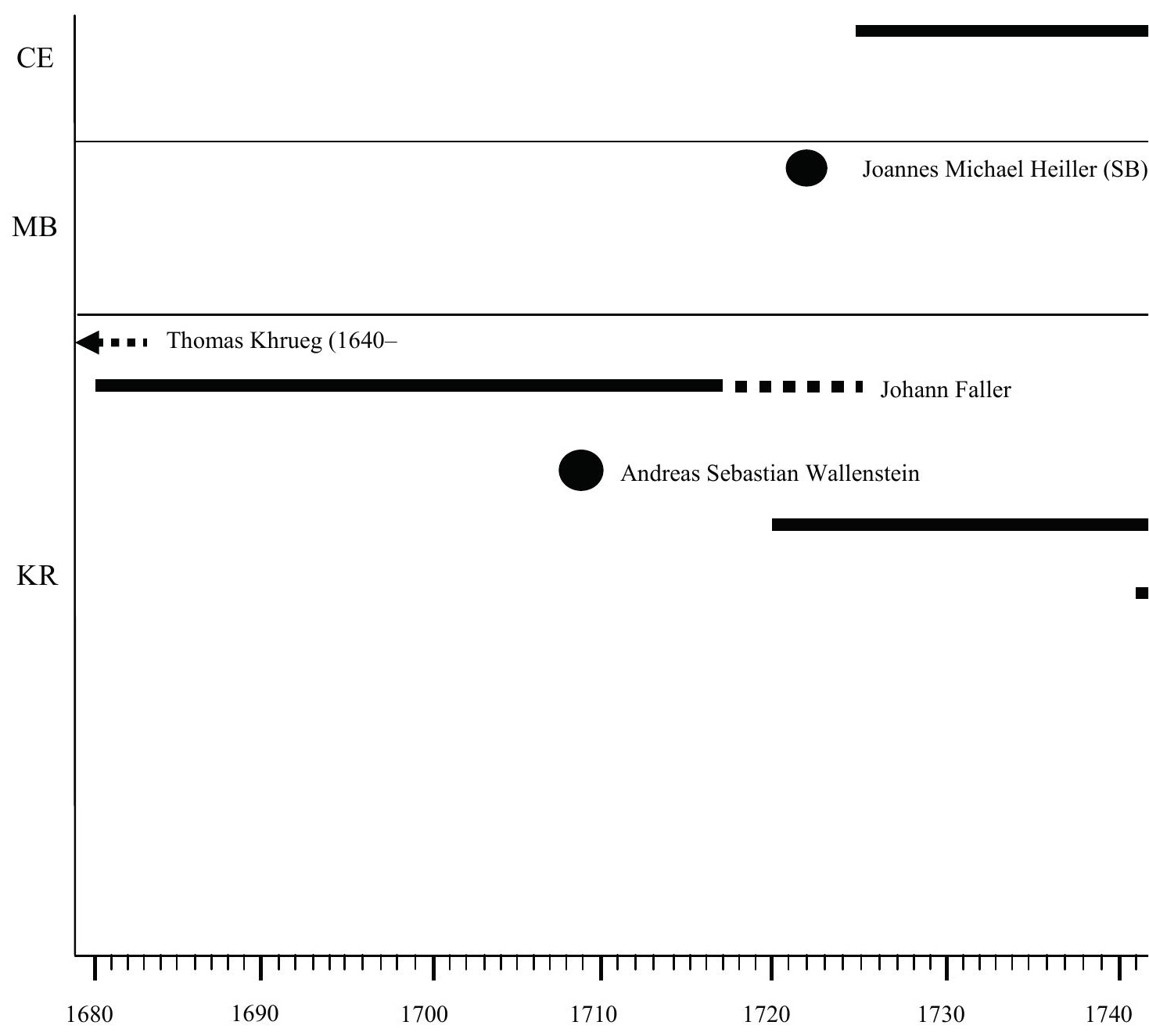


Joannes Franciscus

Janechek

Anton Scholz

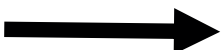

घ घ घ I Simon Ottonitscher

Joseph Ottonitsch

Johann Michael Steihoffer

Marcus Göbl

Johann Georg

Eisl

Joseph Alois Kutschera

Franciscus Xaverius

Crisman

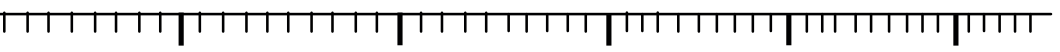

$\begin{array}{lllll}1750 & 1760 & 1770 & 1780 & 1790\end{array}$


V Mariboru je v prvih letih četrtega desetletja še obratovala Ottonitscherjeva delavnica. Po prekinitvi njenega delovanja leta 1832 pa tudi v Mariboru vse do prihoda Jerneja Billicha leta 1837 ni bilo stalnega orglarja (gl. grafični prikaz 3). Videti je, da v letih od 1832 do 1837 na celotnem ozemlju slovenske Štajerske ni bilo delujočih orglarskih delavnic, zato so naročila novih glasbil $\mathrm{v}$ teh petih letih sprejemali predvsem graški orglarji: Mathias Krainz, Karl in Franz Schel ter Jakob Matzinger (gl. tabelo 4).$^{31}$ Domnevno je to tudi razlog, da je bilo v tem času izdelano opazno manj novih orgel na Štajerskem (15) kot na Kranjskem (29).

Slika oglarstva na ozemlju današnje Slovenije se prične spreminjati proti sredini 19. stoletja; od tedaj je produkcija glasbil konstantno močno naraščala. Iz vsakega naslednjega desetletja imamo ok. petnajst glasbil več. Tendenca, da bi imele vse cerkve orgle, se je torej iz desetletja $\mathrm{v}$ desetletje približevala uresničitvi. Za dosego cilja pa je bilo potrebno ustrezno veliko število orglarskih delavnic, ki bi bile zmožne pokriti vsa naročila za izdelavo novih orgel. Na Kranjskem se je orglarstvo krepilo že od časa Johanna Gottfrieda Kunatha dalje (gl. grafični prikaz 4). Ustanavljati so se pričele pomembne delavnice, ki so se ponašale z veliko produkcijo na novo izdelanih glasbil. Takšni sta bili delavnici Petra Rumpla (53) in Ferdinanda Malahovskega (29).

Na ozemlju današnje slovenske Štajerske je bila produkcija orgel nekoliko nižja. Razlog za to je gotovo že omenjeno pomanjkanje orglarjev; Marthalova smrt prinese Celju 17-letni premor, ki ga oživi šele Alois Hörbiger leta 1842; v Mariboru premor nastopi po smrti Josepha Ottonitscha leta 1832. Orglarska dejavnost pa ponovno oživi z nastopom Jerneja Billicha leta 1837. Poleg tega je čas delovanja štajerskih orglarjev opazno krajši od delovanja kranjskih orglarjev; medtem ko je Rumplova delavnica delovala 40 let in izdelala 53 orgel, delavnica Malahovskega pa je v 36 letih izdelala 29 orgel, sta delavnici A. Hörbigerja in J. Billicha delovali le 14 oz. 23 let ter izdelali 17 oz. 12 orgel.

Prav delovanje Aloisa Hörbigerja je poglavitni razlog za nenaden porast števila izdelanih glasbil na Štajerskem v letih med 1840 in 1849 (gl. tabelo 1). V primerjavi z desetletjem poprej se je produkcija podvojila, vendar pa je $\mathrm{v}$ naslednjem desetletju vidno upadla. Ker v tem času na slovenskem Štajerskem poleg Hörbigerjeve in Billichove ni bilo drugih večjih delavnic, je bilo to desetletje glede na število izdelanih glasbil vrhunec oglarstva na ozemlju današnje slovenske Štajerske. Kljub temu, da je od srede stoletja dalje na Štajerskem istočasno delovalo več orglarjev, produkcija ni dosegla števila iz štiridesetih let 19. stoletja.

Ravno nasprotno je bilo $\mathrm{v}$ šestem desetletju. Ko je število izdelanih orgel na slovenskem Štajerskem upadlo, se je vidno povečalo na Kranjskem. V tem desetletju je na Kranjskem delovalo 14 orglarjev, ki so skupno izdelali 50 orgel. Med že uveljavljenimi sta bila Peter Rumpel in Andrej Ferdinand Malahovksy, ki so se jima v tem desetletju pridružili še Peter Rojc, Franc Ksaver Dev in Janez Mandlin. Poleg omenjenih so delovali tudi drugi orglarji, ki so, s sicer precej manjšimi opusi, prav tako pripomogli k večji produkciji orgel (gl. tabelo 5). ${ }^{32}$

${ }^{31} \mathrm{~V}$ tabeli 4 so orglarski mojstri, ki so imeli delavnico na ozemlju današnje Slovenije, potemnjeni.

${ }^{32} \mathrm{~V}$ tabeli 5 so orglarski mojstri, ki so imeli delavnico na ozemlju današnje Slovenije, potemnjeni. 
Tabela 5: Seznam na Slovenskem delujočih orglarjev po letu 1840

\begin{tabular}{|c|c|c|}
\hline Orglar & Obdobje delovanja & Št. orgel \\
\hline Andrej Ferdinand Malahovsky & $1836-1872$ & 29 \\
\hline Jožef Logar & 1836 & 1 \\
\hline Jakob Zmrzlikar & 1837 & 1 \\
\hline Anton Valentinčič & $1840-1855$ & 6 \\
\hline Andrej Göstl & $1840-1877$ & 6 \\
\hline Jernej Billich & $1837-1860$ & 12 \\
\hline Alois Hörbiger & $1841-1855$ & 17 \\
\hline Joseph Papa & 1841 & 2 \\
\hline Peter Rojc & $1843-1875$ & 19 \\
\hline Jože Smole & 1845 & 1 \\
\hline Florijan, Jakob, Martin Mazi & $1845-1850$ & 3 \\
\hline Joseph Salb & $1847-1853$ & 2 \\
\hline Franc Ksaver Dev & 1. pol. 19. stol.-1872 & 15 \\
\hline Andrej Račič & $1850-1865$ & 6 \\
\hline Janko Vrabec & $1864-1877$ & 5 \\
\hline Janez Mandlin & $1838-1875$ & 19 \\
\hline Jakob Špik & $1854-1873$ & 3 \\
\hline Ignacij, Ignacij, Ivan Zupan & $1855-1877$ & 8 \\
\hline Leonhard Ebner & $1855-1868$ & 9 \\
\hline Pietro de Corte & $1855-1864$ & 4 \\
\hline France, Janez Tomaževic & $1855-1858$ & 2 \\
\hline Sandor Országh in sin & 1857 & 1 \\
\hline Franc Naraks & $1857-1877$ & 14 \\
\hline Josef Frenkovič & pr. 1859 & 1 \\
\hline Martin in Jakob Zeichen & $1859-1863$ & 6 \\
\hline Giovanni Tonoli & $1859-1866$ & 2 \\
\hline Franc Pevec & 1860 & 1 \\
\hline Janez Deučman & 1860 & 1 \\
\hline Janez Welley & pr. 1862 & 1 \\
\hline Martin Goršič & 1862 & 1 \\
\hline Adalbert Kafka & $1864-1870$ & 6 \\
\hline Franc Goršič & $1864-1877$ & 24 \\
\hline Dominik Raktelj & 1870 & 1 \\
\hline Alois Hallecker & 1872 & 1 \\
\hline Friedrich Werner & 1872 & 1 \\
\hline Michael Krainz & $1872-1882$ & 4 \\
\hline Matej Sašek & 2. pol. 19. stol. & 2 \\
\hline
\end{tabular}

V zadnjih dveh desetletjih, ki jih razprava še obravnava(1860-1877), je bila produkcija novih orgel enaka povprečju zadnjih šestdesetih let (1820-1877). Na ozemlju današnje slovenske Štajerske sta zadnji desetletji primerljivi s sredino stoletja (1850-1859), na Kranjskem pa število novih orgel nekoliko upade. V tem obdobju so na ozemlju današnje slovenske Štajerske delovale štiri vidnejše delavnice: Franc Naraks v Celju, Martin Zeichen 
Grafični prikaz 3: Štajerski orglarji 19. stoletja

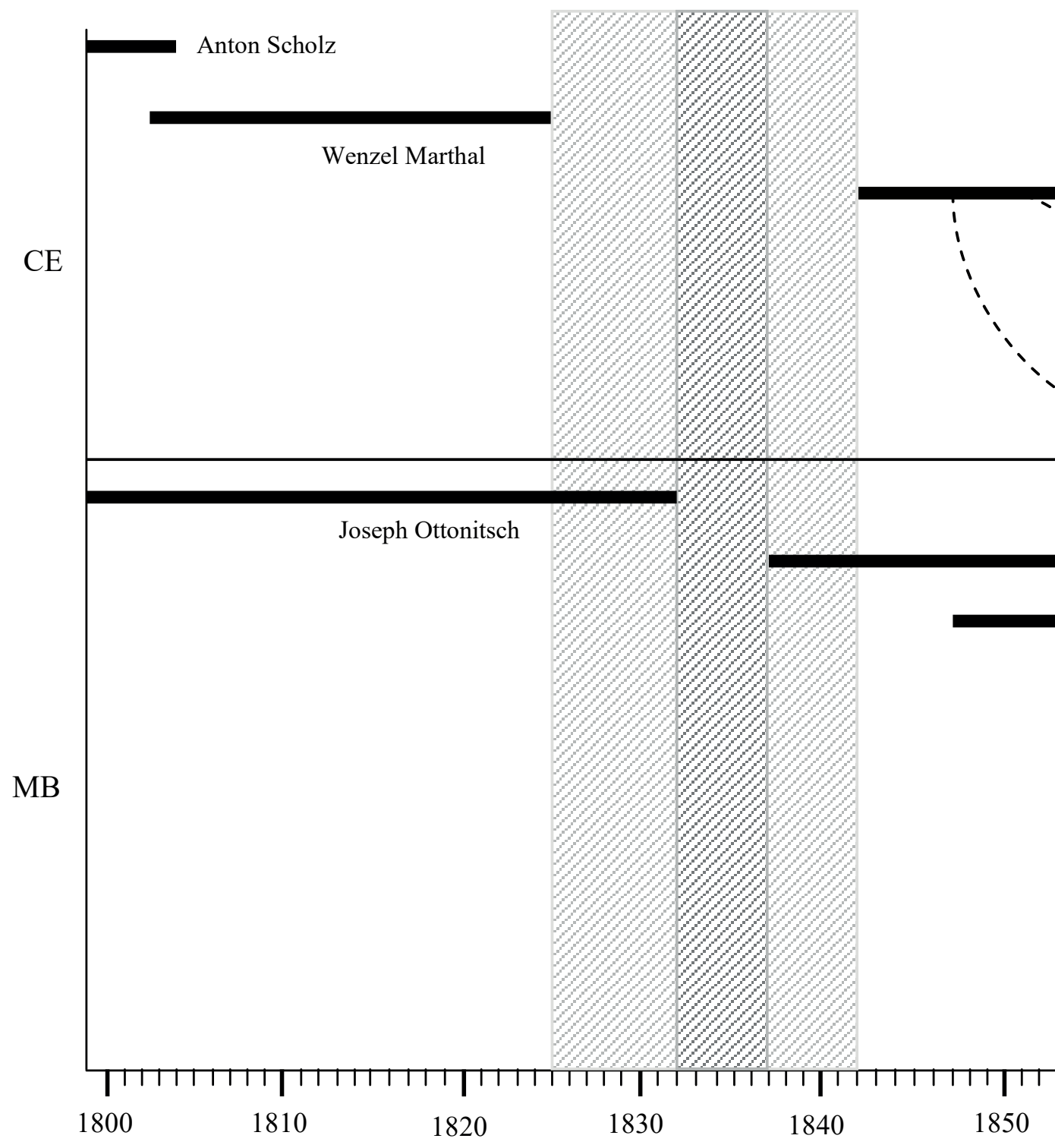




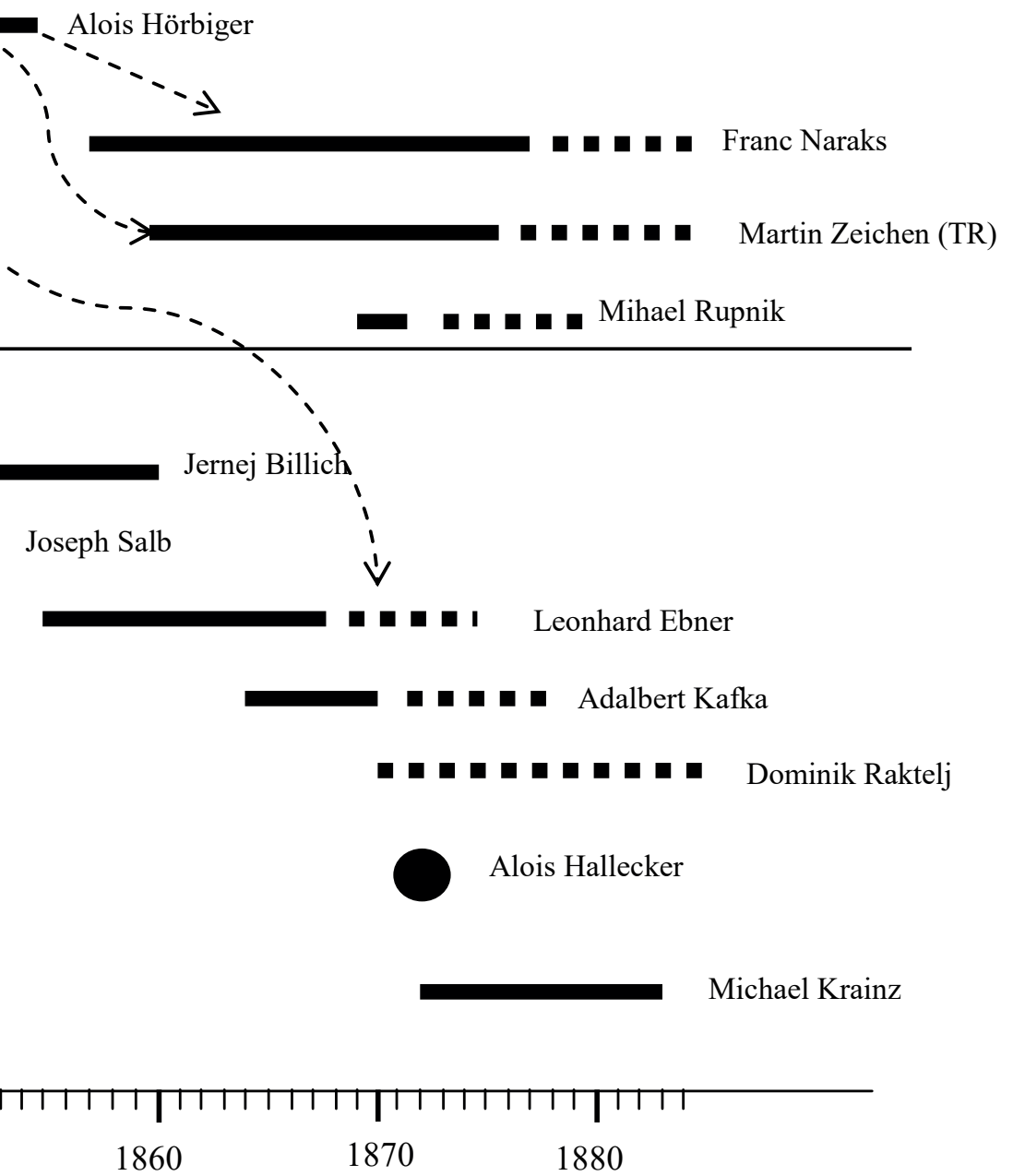


Grafični prikaz 4: Kranjski orglarji 19. stoletja

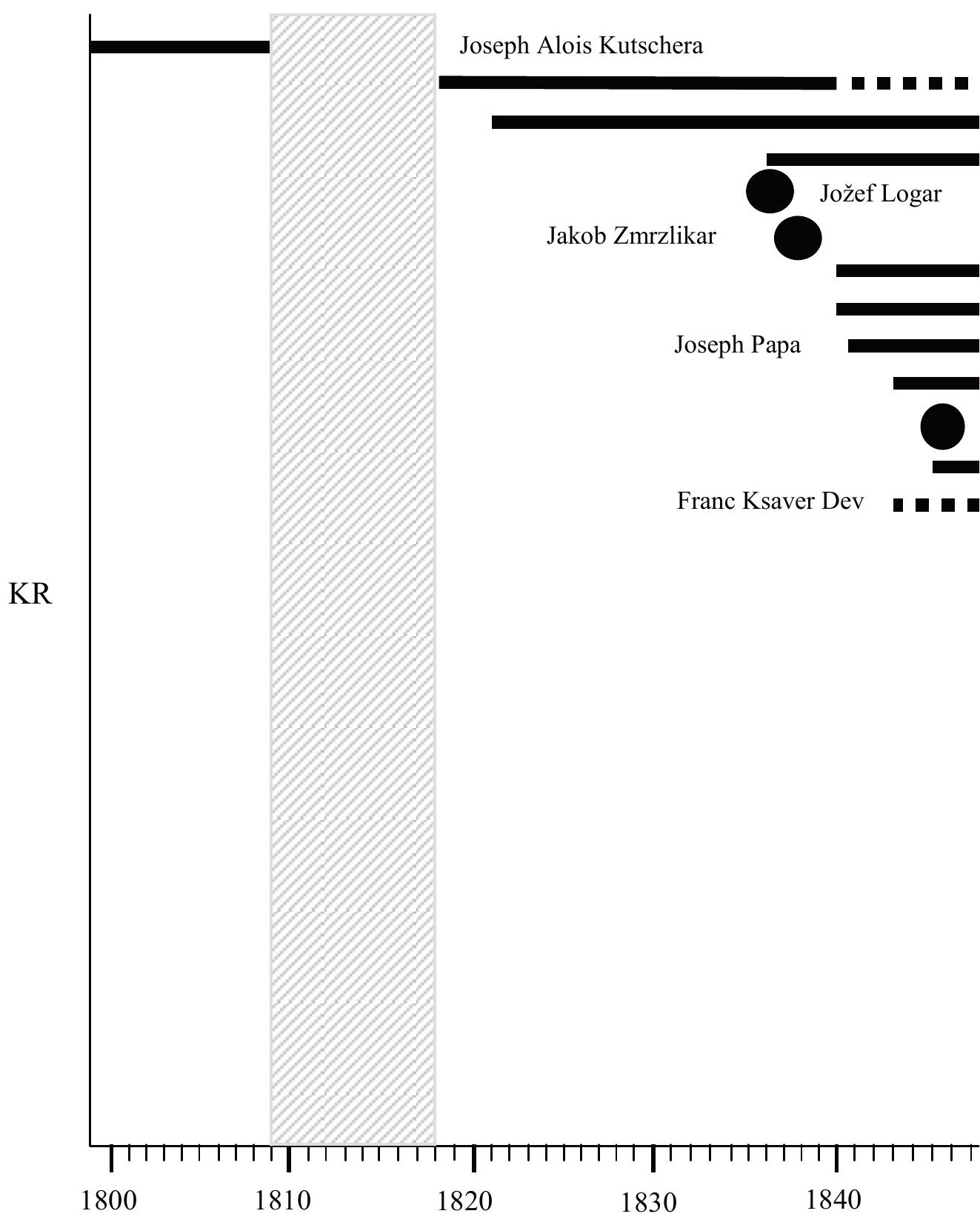


v Trbovljah in Leonard Ebner ter Adalbert Kafka v Mariboru. Najmočnejša med njimi je bila delavnica Franca Naraksa, ki je v prvih dvajsetih letih svojega delovanja (do leta 1877, do koder sega razprava) izdelala 14 orgel za naročnike na ozemlju današnje Slovenije.

$\mathrm{Na}$ Kranjskem je $\mathrm{v}$ tem času delovalo skupaj štirinajst orglarjev, od katerih so bili vidnejši trije (J. Mandlin, A. F. Malahovsky in F. Goršič). Janez Mandlin in Andrej Ferdinand Malahovsky sta bila dejavnejša predvsem v šestdesetih letih; ko sta proti sredini sedemdesetih let zaključevala svojo orglarsko pot, se je v Ljubljani leta 1864 pojavil Franc Goršič. Goršič je bil najvidnejši orglar 19. stoletja na ozemlju današnje Slovenije in kot orglar je bil dejaven vse do smrti leta 1898. V prvih 23 letih (do leta 1877, do koder sega ta razprava) je izdelal kar 24 orgel.

Orglarji, ki so v drugi polovici 19. stoletja delovali na ozemlju današnje Slovenije, so v celoti izpodrinili tu gostujoče orglarje in zmogli izvršiti vsa naročila novih orgel. Gostujoči orglarji so bili prisotni le še na tistih področjih, ki so bila oddaljena od domačih delavnic, zaradi česar so bili orglarji z ozemlja današnjih sosednjih držav »priročnejši«: Pietro de Corte iz Čedada in Giovanni Tonoli iz Brescie sta tako prejemala naročila s severnega dela današnje Primorske, ${ }^{33}$ delavnica Sandorja Országha iz Budimpešte je gostovala v Prekmurju, ki je takrat spadalo pod Madžarsko. Na skrajnem robu današnje slovenske Koroške je eno glasbilo izdelal graški orglar Friedrich Werner, ${ }^{34}$ na Dunaju živeči Janez Deučman, rojen v Jurovskem dolu, pa je izdelal orgle za cerkev v svojem rodnem kraju. ${ }^{35} \mathrm{~S}$ Štajerske je znan še neki »Janez Welley« (morda Johann Welle iz nemškega mesta Lichtenwald). ${ }^{36}$

Težnja, da bi vse župnijske cerkve dobile orgelsko glasbilo, se je v veliki meri uresničila. Na Kranjskem in današnjem slovenskem Štajerskem je bilo v drugi polovici 19. stoletja skupno 260 župnijskih cerkva. Znotraj kranjskih meja, ki so od leta 1833 dalje, po priključitvi dekanij Postojna, Trnovo, Vipava in Motnik, sovpadale z mejami ljubljanske nadškofije, je bilo 142 župnijskih cerkva ${ }^{37}$ in le petnajst jih je bilo do leta 1877 še brez orgel.

Razprava nazorno kaže, kako so si orgle počasi in vztrajno utirale pot v slovenski prostor in postale $\mathrm{v}$ drugi polovici 19. stol. nepogrešljivo glasbilo domala vsake cerkve z rednim bogoslužjem. To pomeni, da so prišle v stik z orglami in orgelsko glasbo kar najširše plasti slovenskega prebivalstva. Prav zato so orgle in orgelska glasba nepogrešljivi del slovenske glasbene in slovenske kulturne zgodovine in predstavljajo pomemben del slovenske kulturne dediščine.

\section{Literatura}

Bizjak, Milko, in Edo Škulj. Orgle na Slovenskem. Ljubljana: Državna založba Slovenije, 1985.

${ }_{33}$ Škulj, Beneške orglarske delavnice, 63; Radole, L'arte organaria in Istria, 143.

${ }^{34} »$ Werner, Friedrich $«$, Österreichisches Musiklexikon.

${ }^{35}$ Švarc, »Iz Goričkega na Štajerskem «, 8.

${ }^{36}$ Eberstaller, Orgeln und Orgelbauer in Österreich, 145.

${ }^{37}$ Šilc, »Župnije in njihov krajevni obseg v ljubljanski škofiji sredi 19. stoletja«, 311. 
Ciglenečki, Marjeta. »Oprema gradov na slovenskem Štajerskem od srede 17. do srede 20. stoletja«. Doktorska disertacija, Univerza v Ljubljani, 1997.

Cvetko, Dragotin. Zgodovina glasbene umetnosti na Slovenskem. 3 zv. Ljubljana: DZS, 1958-1960.

Eberstaller, Oskar. Orgeln und Orgelbauer in Österreich. Wiener musikwissenschaftliche Beiträge, 1. Graz, Köln: H. Böhlaus Nachf., 1955.

Fabjančič, Vladislav. Knjiga ljubljanskih hiš in njenih stanovalcev. Zv. 7, Krakovo. Zgodovinski arhiv Ljubljana (tipkopis iz let 1940-1943).

Heinz, Otmar. Frühbarocke Orgeln in der Steiermark: zur Genese eines süddeutschösterreichischen Instrumententyps des 17. Jahrhunderts. Dunaj: Lit Verlag, 2012.

Höfler, Janez. »Glasbena kapela ljubljanske stolnice v drugi polovici 17. stoletja«. Kronika. Časopis za slovensko krajevno zgodovino 17, št. 3 (1969): 141-147.

-_-. »Glasbeniki koprske stolnice v 17. in 18. stoletju«. Kronika. Časopis za slovensko krajevno zgodovino 16, št. 3 (1968): 140-144.

---. Tokovi glasbene kulture na Slovenskem od začetkov do 19.stoletja. Ljubljana: Mladinska knjiga, 1970.

Kebe, Janez. Loška dolina z Babnim Poljem. Zgodovina župnij Stari trg pri Ložu in Babno Polje. Ljubljana: Družina, 1996.

Klemm, Miroslav, in Zdenko Kušćer. Pozitiv Rudolfa Rapoldta u gradskom muzeju Varaždin 1668-2007. Varaždin: Gradski muzej Varaždin i Atelier Heferer, 2007.

Koter, Darja. Glasbilarstvo na Slovenskem. Maribor: Obzorja, 2001.

---. »Izdelovanje glasbil«. V: Zgodovina glasbe na Slovenskem, zv. 1, Glasba na Slovenskem do konca 16. stoletja, uredil Jurij Snoj, 443-459. Ljubljana: Založba ZRC SAZU, 2012.

Kokole, Metoda. Isaac Posch: "diditus Eois Hesperiisque plagis-Praised in the Lands of Dawn and Sunset”. Frankfurt na Majni: Peter Lang, 2009.

»Kronika samostana Marenberg 1686-1712«. Nadškofijski arhiv Maribor.

Mašek, Kamilo. »O cerkvenem petji in orglanji po deželi«. Kmetijske in rokodelske novice 15 (1857): 170-171, 182-183, 190-191, 198, 207, 214, 274.

Mlinarič, Jože. Kostanjeviška opatija 1234-1786. Kostanjevica na Krki: Galerija Božidar Jakac, 1987.

---. Marenberški dominikanski samostan 1251-1782. Celje: Mohorjeva družba, 1997.

--_. Stiška opatija 1136-1784. Novo mesto: Dolenjska založba, 1995.

Nagode, Aleš. »Starejše slovensko cecilijanstvo in Gregor Rihar«. Muzikološki zbornik 34 (1998): 89-99.

---. »Začetki slovenskega cecilijanstva v luči korespondence med Antonom Foersterjem in Franzom Xaverjem Wittom«. Muzikološki zbornik 43, št. 2 (2007): 83-90.

Owen, Barbara, in Peter Williams. »Organ«. Grove Music Online. Obiskano 20. oktobra 2016.

Pucelj, Pavel. Idiographia sive Rerum memorabilium Monasterii Sitticensis Descriptio. Arhiv republike Slovenije (rokopis iz leta 1719).

Radole, Giuseppe. L'arte organaria in Istria. Bologna: Casa editrice Patron, 1969.

Rijavec, Andrej. Glasbeno delo na Slovenskem v obdobju protestantizma. Ljubljana: Slovenska matica, 1967.

Santonino, Paolo. Popotni dnevniki. Prevedel Primož Simoniti. Celovec: Mohorjeva založba, 1991. 
Slana, Lidija. »Lastniki Rajhenburga med 16. in 19. stoletjem (1570-1881)«. Kronika. Časopis za slovensko krajevno zgodovino 61, št. 3 (2013): 519-540.

Slekovec, Matej. »Turki na Slovenskem Štajerskem. Spominki iz domače zgodovine«. V: Slovenske večernice za pouk in kratek čas, 3-54. Celovec: Družba sv. Mohorja, 1894.

Snoj, Jurij. »Pisna pričevanja o glasbi v ustnem izročilu«. V: Zgodovina glasbe na Slovenskem, zv. 1, Glasba na Slovenskem do konca 16. stoletja, uredil Jurij Snoj, 297-317. Ljubljana: Založba ZRC SAZU, 2012.

Švarc, France. »Iz Goričkega na Štajerskem«. Kmetijske in rokodelske novice 19, 2. januar 1861.

Škulj, Edo. Baročne orglarske delavnice. Škocjan pri Turjaku: Župnija, 2012.

---. Beneške orglarske delavnice. Ob 200-letnici smrti Gaetana Callida. Škocjan pri Turjaku: Župnija, 2013.

-_-. »Orgle v dekaniji Škofja Loka.« 2. del. Loški razgledi 46 (1999): 285-336.

---. Orgle v Ljubljani. Ob 850. obletnici prve omembe Ljubljane v pisnih virih. Celje: Mohorjeva družba, 1994.

---. Orgle v ljubljanski stolnici. Ljubljana: Znanstveno raziskovalni center SAZU, Muzikološki inštitut, 1989.

Šilc, Jurij. »Župnije in njihov krajevni obseg v ljubljanski škofiji sredi 19. stoletja«. Arhivi 29, št. 2 (2006): 305-336.

Trček, Katarina. »Orgle in orgelska glasba v slovenski kulturni zgodovini do nastopa cecilijanstva«. Doktorska disertacija, Univerza v Ljubljani, 2015.

Trček Marušič, Katarina. »The Tradition of Göbl’s Organ Workshop«. V: Glasbene migracije u rano moderno doba: ljudi, tržišta, obrasci i stilovi, ur. Vjera Katalinić, 191-204. Zagreb: Hrvatsko muzikološko društvo, 2016.

Trubar, Primož. Eni psalmi. Tübingen, 1567. Faksimile: Primož Trubar. Eni psalmi. Ljubljana: Cankarjeva založba, 1967.

Voje, Ignacij. Slovenci pod pritiskom turškega nasilja. Ljubljana: Znanstveni inštitut Filozofske fakultete, 1996.

Weigl, Igor. »Prenova gradu Podčetrtek v letih 1715-1723«. Kronika. Časopis za slovensko krajevno zgodovino 47, št. 1-2 (1999): 31-42.

»Werner, Friedrich«. Österreichisches Musiklexikon. Obiskano 5. aprila 2014.

Williams, Peter. »Portative«. Grove Music Online. Obiskano 20. oktobra 2016.

---. »Regals«. Grove Music Online. Obiskano 20. oktobra 2016.

Williams, Peter, in Nicholas Thistlethwaite. »Positive«. Grove Music Online. Obiskano 20. oktobra 2016.

Zadnikar, Marijan. Samostan Stična in njegove znamenitosti. Ljubljana: Družina, 1990. 


\title{
THE DEVELOPMENT OF ORGAN BUILDING IN SLOVENIA UP TO THE CECILIAN MOVEMENT
}

\begin{abstract}
Summary
Up to 1877,779 organs were built in the territory of modern Slovenia according to present knowledge. The exact manufacturing date is known for 576 of them. There is no doubt that these were not the only organs in Slovenian territory until the second half of the nineteenth century. This is a large enough number, however, to give an accurate picture of the dynamic of organ building over the decades. The beginning of organ building in Slovenian territory dates back to the first half of the fifteenth century, when the presence of an organ in the Koper cathedral has been confirmed based on documental evidence of an organist working there. Further development of organ-building slowly and progressively picked up pace even in the seventeenth century, when the first organ workshops in Carniola were opened. The number of newly-built organs grew in the middle of the eighteenth century but notably declined around the turn of the nineteenth century. The organ building experienced a revival in the third decade of nineteenth century and reached a peak in the mid-nineteenth century. By the end of the nineteenth century, organs were already present in almost all the parish churches, and they had become a symbol of liturgical music.
\end{abstract}

